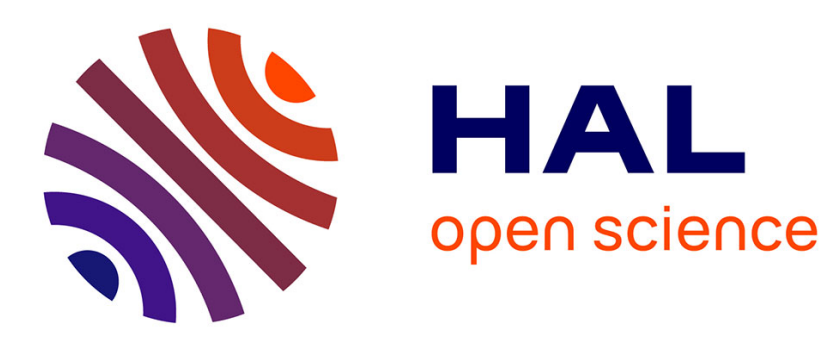

\title{
Habitat selection of an expanding beaver () population in central and upper Morava River basin
}

František John, Shaun Baker, Vlastimil Kostkan

\section{To cite this version:}

František John, Shaun Baker, Vlastimil Kostkan. Habitat selection of an expanding beaver () population in central and upper Morava River basin. European Journal of Wildlife Research, 2010, 56 (4), pp.663-671. 10.1007/s10344-009-0361-5 . hal-00558511

\section{HAL Id: hal-00558511 \\ https://hal.science/hal-00558511}

Submitted on 22 Jan 2011

HAL is a multi-disciplinary open access archive for the deposit and dissemination of scientific research documents, whether they are published or not. The documents may come from teaching and research institutions in France or abroad, or from public or private research centers.
L'archive ouverte pluridisciplinaire HAL, est destinée au dépôt et à la diffusion de documents scientifiques de niveau recherche, publiés ou non, émanant des établissements d'enseignement et de recherche français ou étrangers, des laboratoires publics ou privés. 


\title{
Habitat selection of an expanding beaver (Castor fiber) population in central and upper Morava River basin
}

\author{
František John • Shaun Baker • Vlastimil Kostkan
}

Received: 1 June 2009/Revised: 11 December 2009/Accepted: 16 December 2009/Published online: 22 January 2010

(C) Springer-Verlag 2010

\begin{abstract}
Habitat selectivity by European beaver (Castor fiber L., 1758) was studied in $226 \mathrm{~km}$ of river channels during their colonization of the Morava River basin (the Czech Republic), which had not been occupied by beavers for hundreds of years. The colonization started after initial reintroductions in 1991 and 1992. Annual increases in colonization of the river system from 1995 to 2007 were $15.5 \pm 9.4 \mathrm{SD} \mathrm{km}$ year $^{-1}$ and varied greatly between these years $(\min 0 \mathrm{~km}$, max $33 \mathrm{~km})$. Beavers appeared to be following a dispersal pattern, in which distant sites are often colonized before close-by sites. The selection of habitat variables during the colonization process varied. In the early phase of colonization, there were many areas with optimal habitat that were not occupied by beavers, and habitat selection appeared chaotic. After this early phase, the most significant habitat variable related to beaver occupation was shown to be the presence of willow (Salix spp.) species. In the later phases, the beaver population expanded into suboptimal habitat. Settlement distance from roads, railways, and urbanized areas became less. When
\end{abstract}

Communicated by H. Kierdorf

F. John $(\bowtie) \cdot$ S. Baker $\cdot$ V. Kostkan

Department of Ecology and Environmental Sciences,

Faculty of Science, Palacky University,

tř. Svobody 26,

77146 Olomouc, Czech Republic

e-mail: frantisek.john@post.cz

S. Baker

Torc Ecology Ltd,

25 Station Road, Snettisham, King's Lynn,

Norfolk, UK PE31 7QL

e-mail:shaun@torcecology.co.uk comparing the generalized linear models, a model from the winter of 2003/2004 had the best overall accuracy and showed excellent agreement among observed and fitted values (Cohen's $\kappa=0.75$ ). The model suggests that beavers established their home ranges at first in optimal habitat, which had not been occupied before and then subsequently in suboptimal/marginal areas.

Keywords Alluvial forests · Castoridae · Danube basin . GIS $\cdot$ Riparian habitats $\cdot$ Species reintroduction

\section{Introduction}

After an absence of almost 260 years, thanks to a successful reintroduction program and a continued natural population expansion, the European (Eurasian) beaver (Castor fiber L., 1758) has colonized most of the Morava River basin. Population development and colonization started after the release of 22 animals caught from the wild, which were released over a 6-year period, in 1991, 1992, and 1996 into the Litovelské Pomoraví Protected Landscape Area (PLA; Fig. 1). For the reintroduction, European beavers of the subspecies C. fiber vistulanus Matschie, 1907 from the Suwalki area of north-east Poland $(n=20)$ and from Lithuania $(n=2)$ were chosen (Kostkan and Lehký 1997; Šafár 2002). Many channels of the Morava River flow through Litovelské Pomoraví PLA maintaining a natural water regime surrounded by well-preserved alluvial forests (Fig. 1). The channels in the Morava River basin with optimal beaver habitat, such as that suggested by MüllerSchwarze and Sun (2003) with slowly meandering streams with alder Alnus spp. or willow Salix spp. thickets near the water, appear to be already settled by beavers with beavers 
Fig. 1 Map of the study area showing the dated location of beaver release sites and maximum dispersal distances

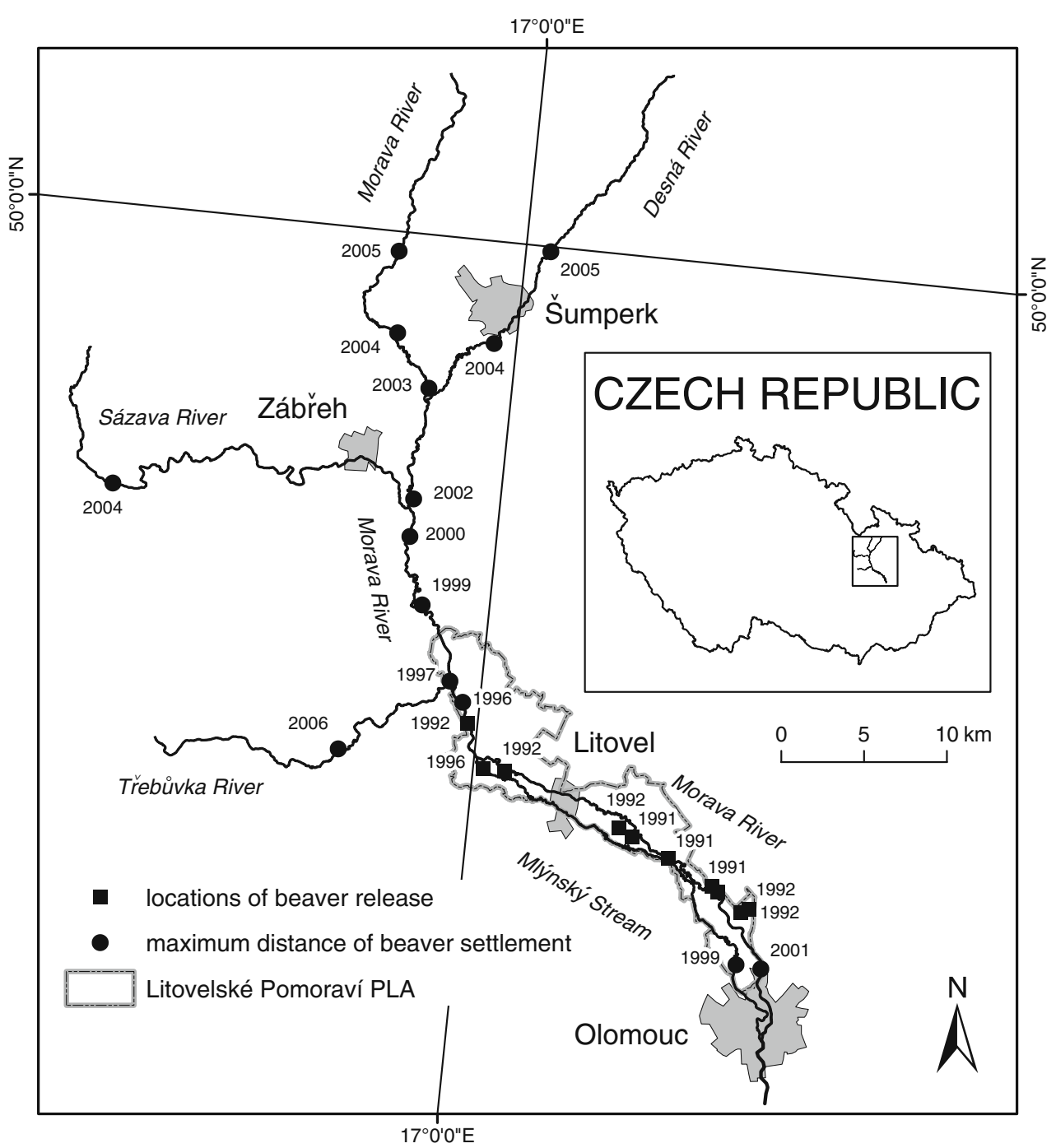

still expanding deeper into less optimal channels. There are no beaver dams in the studied river channels, principally because they provide stable water levels, and moreover, the main river channel is too large for beavers to dam (Hartman and Tornlov 2006).

Most studies of habitat selection by beavers are short term and generally treat resource use as though it is temporally static on an annual scale (Schooley 1994). Studies carried out on both beaver species European beaver C. fiber and North American beaver Castor canadensis mostly contain only data obtained during one season (Slough and Sadleir 1977; Beier and Barrett 1987; Dieter and McCabe 1989; McComb et al. 1990; Robel et al. 1993; Hartman 1996; Barnes and Mallik 1997; Suzuki and McComb 1998; Fustec et al. 2001; Fustec et al. 2003). Howard and Larson (1985), Broschart et al. (1989), and Fryxell (2001) have all described habitat selection based on a longer period, however, but the research was conducted in study areas which were already occupied by beavers when the research began.
Hartman (1996) highlights that beaver habitat studies carried out in populations which are near carrying capacity may give little information about quality or preference of habitat but rather give more appropriate information on usable and unusable habitat. Hartman (1994; 1995) evaluated long-term beaver population development and colonization patterns in Sweden, but the data of beaver occurrence was not sufficiently compounded with habitat selection.

The colonization process, which corresponds with beaver dispersal and settlement, has mostly been studied at the individual level using telemetry (Beer 1955; Leege 1968; Sun et al. 2000; Campbell et al. 2005; McNew and Woolf 2005). The data on beaver dispersal, however, were not sufficiently related to habitats. Only Nolet and Rosell (1994) have combined studies on sequential settlement by beavers with habitat selection.

The aim of this work was to examine habitat selection by European beavers during colonization of river channels, which had not been occupied by beavers for hundreds of years. 


\section{Materials and methods}

Study area

The study area was in Moravia (the Czech Republic) and covered the Morava River basin (Danube basin) upstream of the city of Olomouc (Fig. 1). The Morava River section studied comprises a stretch of channels $95 \mathrm{~km}$ in length, which fall from $500 \mathrm{~m}$ a.s.l. in Hanušovice at 330th r. kilometer to $205 \mathrm{~m}$ a.s.1 in Olomouc at 233rd r. kilometer. Third/fourth order rivers/channels were selected to be studied based on the presence of beaver and were studied upstream from their confluence with the Morava River; $31 \mathrm{~km}$ of the Desná River, $39 \mathrm{~km}$ of the Sázava River, and $26 \mathrm{~km}$ of the Trrebůvka River were studied. The full length of the seminatural channel Mlýnský Stream was also studied $(35 \mathrm{~km})$.

The channels flow initially from narrow valleys where they are generally surrounded by ash-alder alluvial forests dominated by European alder (Alnus glutinosa L.) or ash tree (Fraxinus excelsior L.) and small agricultural and urban landscapes, to wide open plains where they are surrounded by relatively well-preserved alluvial forests and larger agricultural and urban landscapes. Alluvial forests on the plains are characterized by three natural plant communities. Near the water or in the water during floods is generally where the riverine willow scrub is located including willow species such as almond-leaved willow (Salix triandra L.), common osier (Salix viminalis L.), purple osier (Salix purpurea L.), and crack willow (Salix fragilis L.). The second plant community willowpoplar forests are dominated by white willow (Salix alba L.), crack willow (S. fragilis L.), and black poplar (Populus nigra L.). On the top of the riverbank occurred hardwood forests dominated by common oak (Quercus robur L.), European alder, and ash trees, accompanied by small-leaved lime (Tilia cordata L.), European hornbeam (Carpinus betulus L.), and bird cherry (Padus avium Mill.).

The water regime along the channels is mostly regulated and the banks are often stabilized by boulders. At the downstream end of the study area, the Morava River has an average flow of $20 \mathrm{~m}^{3} \mathrm{~s}^{-1}$, and the drainage area is $4,565 \mathrm{~km}^{2}$. Annual precipitation ranges from 550 to $800 \mathrm{~mm}$, and mean temperature ranges from $7.5^{\circ} \mathrm{C}$ to $8.5^{\circ} \mathrm{C}$. In cold winters some stream sections are covered by ice for several weeks.

The study area is partly covered by Litovelské Pomoraví PLA, a Ramsar Wetland of International Importance, which is also situated in a Site of Community Importance CZ0714073 - designated under the European Commission Directive on the conservation of natural habitats and of wild fauna and flora $(92 / 43 / \mathrm{EEC})$.
Data collection

\section{Colonization of the river system}

Colonization of the Morava River basin upstream from the city of Olomouc by a reintroduced beaver population has been monitored since the initial reintroduction in 1991 and 1992. The river channels were subdivided on the basis of aerial photography (pixel $0.5 \mathrm{~m}$, optimizing for the scale 1:5,000, Geodis Brno 2003) in Geographic Information System (GIS) software (ArcView v. 3.1, Environmental Systems Research Institute) into sections $500 \mathrm{~m}$ in length. For each section the absence or presence of regular beaver settlement was recorded and input to GIS during the winters $1993 / 1994$ to $2006 / 2007$. Prior to 2001 , the history of beaver settlement was compiled from field notes, thesis, and literature (Kostkan 2000; Šafář 2002; John 2006, 2009). After 2001, all channels were surveyed by foot or by boat at least once every 2 years. The presence of active beaver colonies (beaver settlements) was recorded during winter (December through to March) using a hand-held Geographic Positioning System receiver to record individual signs of recent beaver activity (e.g., new timber cuts or bark stripping, lodges/bank dens with evidence of recent beaver activity). If the channel had not been surveyed in the previous year, 1-year-old beaver activity signs were also recorded. The maximum distance of colonization was measured for each year as the distance separating each new beaver settlement from the nearest settlement occupied in the previous year. The ends of the sections where beaver activity signs were last recorded were also surveyed $10 \mathrm{~km}$ upstream and downstream to ensure all settlement sites where identified. The decision to limit the survey by this value was taken based on the premise that this value is smaller than the annual increases in colonization of the river system which were observed in the study from 1995 to $200516 \pm 10$ SD km year ${ }^{-1}$ (John 2006).

\section{Habitat characteristics}

For each 500-m section of river channel, five physical and two vegetation variables were estimated using GIS: water shed area; stream width; stream gradient; stream sinuosity; distance from roads, railways, and urbanized areas; willow cover and canopy cover. Evaluated habitat variables were chosen based on their use in other beaver habitat studies and the ease to which they can be observed and used in GIS. Habitat variables: stream width, stream gradient, and upstream watershed area have no direct physiological relevance for beaver performance but relate to water conditions. Sinuosity was found to be an important geomorphic and topographic variable by Hartman (1996). Distance from roads, railways, and urbanized areas relate to 
human disturbance of beavers, which can influence beaver behavior. This type of infrastructure can restrict beaver activity at certain times of the day and night, and heavy metals from road runoff may affect beaver physiology. Moreover, road kills can have a direct affect on the beaver population. Evaluated vegetation variables relate to beaver use of timber focusing on willow species for food, security, and building resources, as willow was the dominant tree species within the study area and formed the vast majority (77\%) of all cut trees in the study area (John and Kostkan 2009).

To increase measurement of some variables, both river banks were delineated on the basis of aerial photography in GIS. The width of the channel was analyzed in GIS using these delineated banks. Every section along the left bank was subdivided into ten 50-m sections, to which measurements were taken and then averaged. Sinuosity was measured as a proportion of the length of the section $(500 \mathrm{~m})$ and a straight line from one end of the section to the other. The stream gradient was expressed as a percentage slope. A 1:25,000 topographic map was used to identify the elevations at the downstream and upstream end of the sections. To determine the stream gradient, we divided the vertical drop by the length of the section. The upstream watershed area was determined using a 1:50,000 hydrologic map. The shortest distance between the center of the section and roads, railways, and urbanized areas was measured using GIS and the shortest distance to either of these recorded. Tree canopy cover was analyzed using GIS; on the basis of aerial photography, patches covered by trees or scrub were digitized at a distance of up to $50 \mathrm{~m}$ from the water's edge on both banks. The decision to evaluate canopy cover at this distance from the water's edge was based on earlier observations within the study area of the limits of beaver activity signs (Kostkan et al. 2002; John and Kostkan 2009). From May to September 2004 and 2007 , field work was conducted to identify areas of willow at each stream section.

\section{Data analysis}

To analyze habitat selection, we used the K-select analysis (Calenge et al. 2005), relying on the concept of ecological niche (Hutchinson 1957) that was primarily designed for radio tracking habitat selection studies in which habitat availability varies from animal to animal. This enabled the $\mathrm{K}$-select analysis to be used to study habitat selection during the colonization process when habitats available to beavers varied. Analysis was carried out using R software (Ihaka and Gentleman 1996; R Development Core Team 2007) within package Adehabitat (Calenge 2006).

Binominal generalized linear models (GLMs) with a logit link function were used to model beaver distribution. For each field season, the model with the lowest Akaike information criterion (AIC) was selected. The same datasets used to construct the GLMs were also used to evaluate the models based on the agreement between observed and predicted beaver occurrence. Habitat use was predicted binomially as the presence or the absence of beaver; the values predicted by the GLMs were used after inverse link transformation to predict the presence/absence of beavers (threshold value $=0.5$ ). The performance of the GLMs was evaluated using the $\kappa$ statistic, which describes the proportion of the correctly classified predictions after the probability of chance agreement has been removed (Cohen 1960): $\kappa=(D-Q) /(n-Q)$, where $D=a+d, Q=$ $[(a+b)(a+c) / n]+[(c+d)(b+d) / n], a$ is the number of true positives correctly predicted, $b$ is the number of false positives incorrectly predicted, $c$ is the number of false negatives incorrectly predicted, $d$ is the number of true negatives correctly predicted, and $n$ is the overall number of the cases; $a+b+c+d$. The $\kappa$ values of $0-0.4$ indicate poor agreement, $0.4-0.75$ indicates good agreement, and 0.75-1.0 indicates excellent agreement (Landis and Koch 1977). GLMs were constructed using the design package (Harrell 2007) in R software (Ihaka and Gentleman 1996; R Development Core Team 2007).

\section{Results}

\section{Colonization of river system}

Colonization of the river system by beavers dispersing from release sites started 3 years after the initial releases. Annual increases in colonization of the river system from 1995 to 2007 were $15.5 \pm 9.4 \mathrm{SD} \mathrm{km} \mathrm{year}{ }^{-1}$ and varied greatly between these years $(\min 0 \mathrm{~km}$, $\max 33 \mathrm{~km})$. The beavers appeared to be following a spatially discontinuous dispersal pattern in which distant sites were often colonized before close-by sites.

Following a static 3-year stage after the initial release, the year-to-year change in the number of river sections occupied by beavers steadily increased up to the winter of 1999/2000. During the winter of 1999/2000, almost twice as many channels were occupied than in the previous winter (Table 1). In 2006/2007, $90 \mathrm{~km} \mathrm{(39.8 \% )} \mathrm{of} \mathrm{the}$ $226 \mathrm{~km}$ of river channels surveyed were occupied by beavers.

\section{Habitat features}

Of the evaluated river system, mean width of channels was $13 \pm 6$ SD m (range 4-42), mean sinuosity was $1.2 \pm 0.35$ SD (range 1-3.8), mean upstream watershed area was 1,088 $919 \mathrm{SD} \mathrm{km}^{2}$ (range 44-3,297), mean channel gradient was $2.7 \pm 3.7 \%$ (range $0.1-24$ ), mean distance from roads, 
Table 1 Results of the randomization tests of habitat selection by beavers during colonization

\begin{tabular}{|c|c|c|c|c|c|c|c|c|c|c|c|}
\hline \multirow[t]{2}{*}{ Winter } & \multicolumn{2}{|c|}{ (a) Channel sections } & \multicolumn{2}{|c|}{ (b) Test of the marginality } & \multicolumn{7}{|c|}{ (c) Selection of habitat variables in each year } \\
\hline & In SA & Occupied & Marginality & $p$ value & WatA & Sinuosity & Gradient & Width & Canopy & Willow & RoadsD \\
\hline 1993/1994 & 145 & 8 & 0.801 & 0.0005 & 0.120 & -0.212 & 0.083 & $-0.606^{\mathrm{a}}$ & -0.050 & $-0.598^{\mathrm{a}}$ & 0.081 \\
\hline $1994 / 1995$ & 145 & 10 & 0.377 & 0.0141 & 0.121 & -0.197 & 0.017 & $-0.458^{\mathrm{b}}$ & 0.142 & -0.285 & 0.109 \\
\hline $1995 / 1996$ & 167 & 8 & 0.454 & 0.0056 & 0.062 & 0.151 & -0.171 & $-0.414^{\mathrm{b}}$ & 0.069 & 0.201 & $-0.425^{\mathrm{b}}$ \\
\hline $1996 / 1997$ & 203 & 12 & 0.587 & 0.0025 & 0.271 & 0.181 & -0.094 & 0.325 & 0.242 & $0.555^{\mathrm{b}}$ & 0.002 \\
\hline $1997 / 1998$ & 210 & 14 & 1.034 & 0.0002 & 0.250 & 0.082 & -0.077 & 0.417 & 0.301 & $0.833^{\mathrm{a}}$ & -0.013 \\
\hline $1998 / 1999$ & 210 & 21 & 1.567 & 0.0001 & 0.271 & 0.000 & -0.176 & $0.489^{\mathrm{b}}$ & $0.572^{\mathrm{b}}$ & $0.916^{\mathrm{a}}$ & 0.239 \\
\hline $1999 / 2000$ & 232 & 41 & 1.396 & 0.0001 & 0.344 & 0.114 & -0.210 & 0.250 & 0.469 & $0.932^{\mathrm{a}}$ & 0.264 \\
\hline $2000 / 2001$ & 261 & 73 & 1.307 & 0.0002 & 0.459 & 0.381 & -0.217 & 0.400 & 0.369 & $0.655^{\mathrm{a}}$ & 0.422 \\
\hline $2001 / 2002$ & 261 & 85 & 1.565 & 0.0001 & 0.473 & 0.473 & -0.261 & 0.291 & 0.508 & $0.631^{\mathrm{a}}$ & $0.555^{\mathrm{b}}$ \\
\hline $2002 / 2003$ & 261 & 124 & 1.016 & 0.0005 & 0.444 & 0.257 & -0.216 & 0.155 & 0.447 & 0.455 & 0.524 \\
\hline $2003 / 2004$ & 312 & 143 & 1.306 & 0.0002 & $0.629^{\mathrm{b}}$ & 0.260 & -0.331 & 0.185 & 0.455 & 0.439 & $0.547^{\mathrm{b}}$ \\
\hline $2004 / 2005$ & 388 & 164 & 1.552 & 0.0001 & $0.735^{\mathrm{a}}$ & 0.328 & $-0.481^{\mathrm{a}}$ & 0.221 & 0.410 & 0.401 & $0.544^{\mathrm{b}}$ \\
\hline $2005 / 2006$ & 428 & 172 & 1.950 & 0.0001 & $0.782^{\mathrm{a}}$ & 0.388 & $-0.723^{\mathrm{a}}$ & 0.210 & 0.404 & 0.399 & $0.547^{\mathrm{b}}$ \\
\hline $2006 / 2007$ & 452 & 180 & 1.974 & 0.0001 & $0.813^{\mathrm{a}}$ & 0.387 & $-0.667^{\mathrm{a}}$ & 0.269 & 0.424 & 0.428 & 0.531 \\
\hline
\end{tabular}

The tests are based on 10,000 randomization steps. (a) Evaluated stream sections, In SA = stream sections considered as available for beavers in study area $(n)$, Occupied = with presence of beaver home range assessed based on the presence of active beaver signs. (b) Significance of the marginality in each year, Bonferroni $\alpha$ level $=0.05 / 14=0.0035$. (c) Coordinates of marginality vectors on habitat variables (i.e., the differences [mean used-mean available] for each year and each variable, Bonferroni $\alpha$ level $=0.05 / 98=0.0005$ ). WatA $=$ watershed area, RoadsD $=$ distance from roads and urbanized areas

${ }^{a}$ Significant at $5 \%$ level

${ }^{\mathrm{b}}$ Significant at $10 \%$ level

railways, and urbanized areas was $250 \pm 294 \mathrm{SD} m$ (range $0-1,552)$, mean area of canopy cover was $17,725 \pm$ $13,150 \mathrm{SD} \mathrm{m}^{2}$ (range $0-48,841$ ), and mean area of willow was $3,040 \pm 4,898 \mathrm{SD} \mathrm{m}^{2}$ (range 0-32,816).

\section{Habitat selection}

Based on the randomization tests on the marginality vectors, habitat use was significantly nonrandom in each year of the study (Table 1). The randomization tests for each year and each variable indicated that from 1996/1997 to $2001 / 2002$, channel sections with a higher area of willow were used significantly more than expected under the hypothesis of random use. The difference between used and available willow was greatest in 1999/2000; after that, the significance of this variable in relation to the others declined. In the later phases of the study, from 2004 to 2007 when the channel gradient became a more significant variable, the difference between usage and availability of this variable had increased. After 2003/2004, channel sections with a higher gradient were used significantly less than what had been expected under random use. Other significant variables in later phases of the colonization were the area of watershed and distance from roads, railways, and urbanized areas (Table 1).
The first eigenvalue of the K-select analysis is larger than expected under the random habitat use hypothesis, $\lambda_{1}=0.975(p<0.0001)$; the next two eigenvalues are $\lambda_{2}=$ 0.147 and $\lambda_{3}=0.040$. The progress of habitat selection during the colonization process is illustrated in the charts of K-select analysis (Fig. 2). Habitat selection appeared chaotic during the first 3 years following the initial release. This was due in part to a low population density and human choice of release sites. After the first 3 years when the beaver population started to expand, beavers selected wide river channels with a high-percentage canopy cover of willow to settle. After 2003/2004, beavers were more likely to settle in channels with a higher gradient, smaller watershed, and at a shorter distance to roads, railways, and urbanized areas.

Models used to predict beaver colonization during the early years after reintroduction showed poor prediction rates mainly because they predicted beaver occupation in many areas of optimal habitat, but the beavers were not there. After 7 years up to the winter of 2003/2004, models slowly showed better overall accuracy and quality of predictions. Following the winter of 2003/2004, the quality of model predictions slowly declined (Table 2 ). In the best fit GLM $(d f=6, p<0.0001$, adj. D-squared $=0.57)$, which was applied to the data from winter 2003/2004, the areas of 


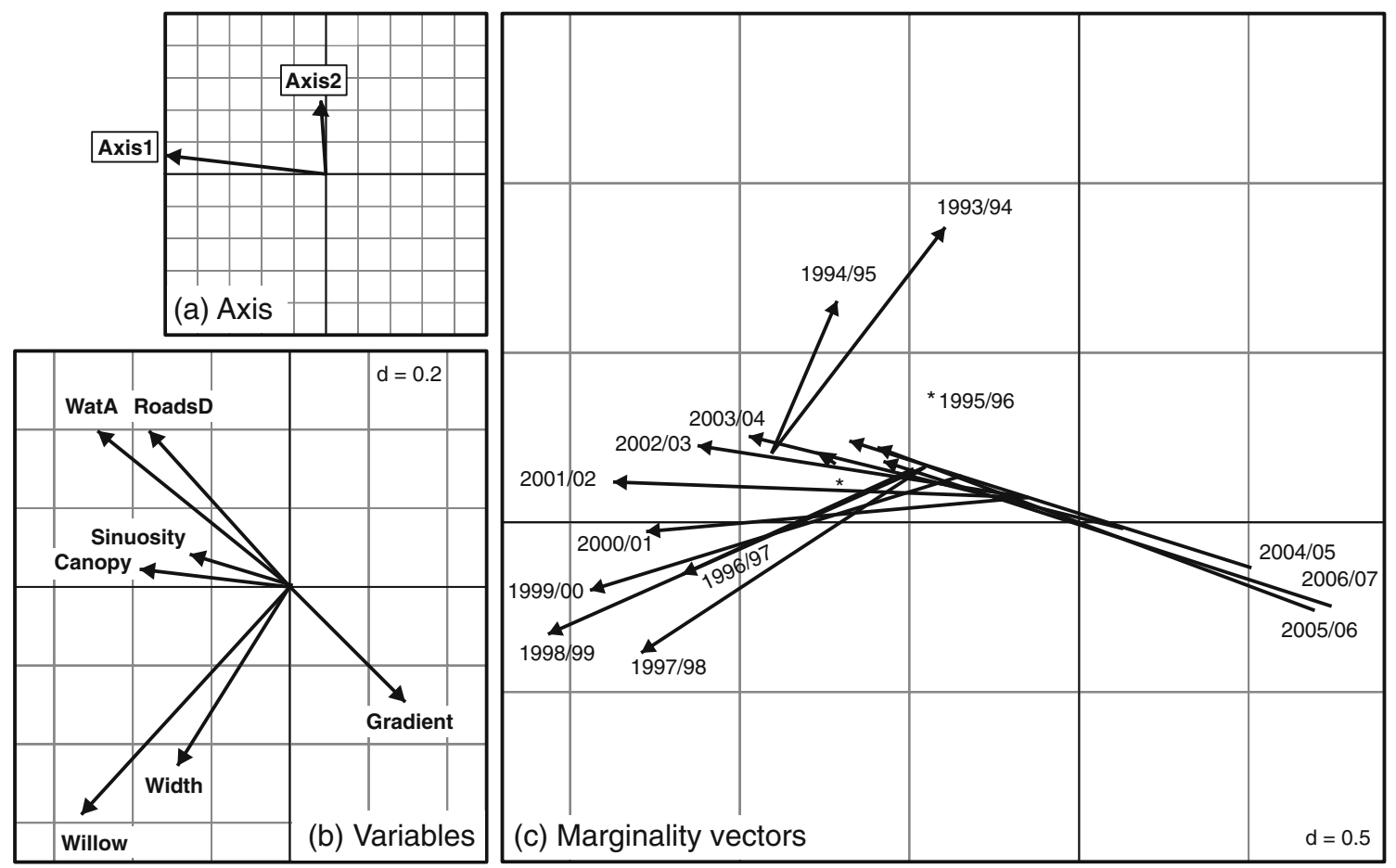

Fig. 2 Results of K-select analysis carried out to highlight habitat selection during colonization of the Morava River basin upstream from the city of Olomouc. a The correlation between the axes of the $\mathrm{K}$-select analysis and the first two axes of the PCA. b The scores of the environmental variable loadings on the first two factorial axes. c

watershed, sinuosity, gradient, width, willow cover, and distance from roads, railways, and urbanized areas, were all used as explanatory variables. A $\kappa$ value of 0.75 showed excellent agreement for this model. This may suggest that before 2003/2004, not all optimal habitats were occupied by beavers, and after 2003/2004, beavers were more likely to settle in less optimal habitat.

\section{Discussion}

Over the 260 years that beavers have been absent from the Morava River basin, the riverine system has remained relatively unaltered with only a few river sections regulated. Some man-made fish ponds, dating back to the Middle Ages, still remain within the flood plains, and it was in these fish ponds that beavers were first hunted in order to protect fish stocks from beaver activities (Hošek 1966). It was only during later centuries that beavers became commercially hunted for meat, fur, and glands. It seems likely therefore that beavers became extinct in the Morava River basin in the early eightieth century due to over hunting rather than habitat loss.

The vast majority of this study was carried out within this relatively unaltered habitat along the meandering river channels with a natural water regime, surrounded by flood
The uncentered vectors on marginality for each winter (the origin of the arrow indicates the centroid of the cloud of available points, and its end indicates the centroid of the cloud of used points). WatA watershed area, RoadsD distance from roads and urbanized areas)

plain alluvial forests, which constitutes prime beaver habitat (Nolet and Rosell 1998; Müller-Schwarze and Sun 2003) in the Morava River basin.

The fundamental results of the study were that in such prime habitat during colonization, shortly after a reintroduction, European beavers appear to follow a spatially discontinuous dispersal pattern. In which, more distant sites are often colonized before close-by sites. Beavers establish their colonies in optimal habitat first, before they occupy suboptimal/marginal habitats, with the relative explanatory power of variables associated with beaver settlement changing over time.

Initial phases of European beaver expansion along the Morava River basin

Natural colonization of beavers started 3 years after the initial release, which corresponds with movement of beavers from their natal colony in their second or third year of life before breeding (Hartman 1997). The annual increase of beaver population range was similar to other published studies. The distance traveled by colonizing beavers in the Loire River (France) averaged $8.8 \pm$ $12.8 \mathrm{SD} \mathrm{km}$ year $^{-1}(\min 0 \mathrm{~km}, \max 80 \mathrm{~km}$; Fustec et al. 2001) and in a Swedish study averaged $12-19.7 \mathrm{~km}$ year $^{-1}$ (Hartman 1995). As in our study, these studies showed that 


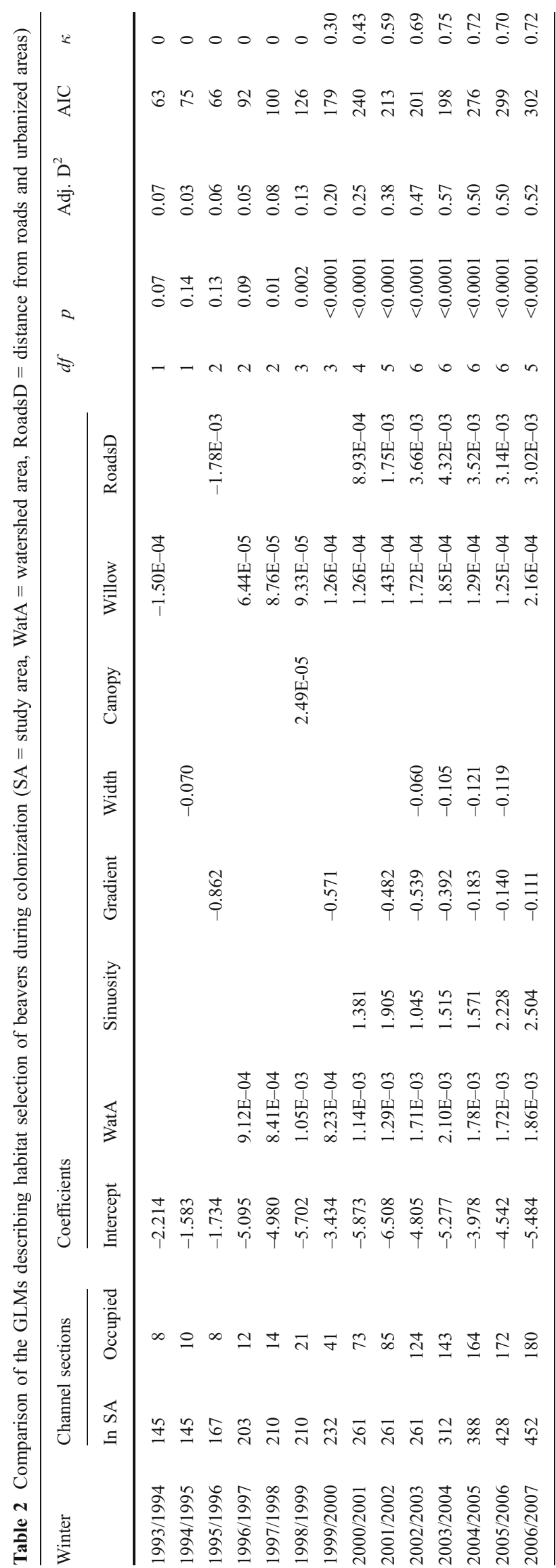

natural colonization by beavers often involved settlement of distant sites earlier than those close to previously occupied sites.

Many of the physical variables studied (e.g., channel width, channel gradient, and area of watershed) were related to water conditions, which when combined with resource availability represent key factors in habitat suitability for beavers (Slough and Sadleir 1977; Howard and Larson 1985; Dieter and McCabe 1989; McComb et al. 1990; Fustec et al. 2001). Although the explanatory power of habitat variables changed during the colonization process. During the initial expansion phases of the colonization, the most important habitat variable for beavers setting up home ranges in our study was the area of willow available. Although other studies have concluded that vegetative variables added little to beaver habitat models and identified geomorphic channel variables as more important (Beier and Barrett 1987; Hartman 1996; Suzuki and McComb 1998), this study seems to suggest that beavers actively seek out areas dominated by willows during their expansion phase along the Morava River basin. Indeed, early observations by Zurowski and Kasperczyk (1990) appear to suggest that a recently reintroduced beaver population will tolerate environments with extreme water fluctuations in order to settle close to willow habitat. Therefore, willow habitat may be an important predictive variable for beaver settlement in both optimal and suboptimal/marginal habitat during expansion phases before a population reaches its climax capacity. However, care must be taken when interpreting both the results of this study and those of Zurowski and Kasperczyk (1990) as no data are provided on tree species composition within the studied areas, only the occurrence of beaver settlements in relation to willow stands.

Later phases of European beaver expansion along the Morava River basin

In the studied river channels, beavers did not modify water levels by building dams, but they did have an effect on the structure of the riparian forests (Kostkan et al. 2002). In felling willows, which subsequently reshoot from the remaining stumps, beavers create an increased biomass and change the structure of the riparian zone by opening up the ground layer (Kindschy 1985; Fustec et al. 2001).

If willow resources can be protected from other natural processes, Aleksiuk (1968) believes territorial behavior of beavers to be a self-regulating mechanism which prevents resource depletion. This type of territorial behavior has been shown in small telemetry trails carried out within the study area. In these trails settlement pattern was found to be influenced by high territoriality of beavers, as described by (Nolet and Rosell 1994; Campbell et al. 2005). This pattern 
is regarded as evidence that territorial behavior may limit population density and appears to fit the assumption of Nolet and Rosell (1994) that the number of beaver territories is often smaller than the carrying capacity of the habitat predicted for sequential settlement in linear habitats. According to the hypothesis of territoriality, newcomers are prevented from settling by aggressive residents, which describes an ideal despotic distribution where group territoriality limits population density in beavers (Aleksiuk 1968).

Colonization of anthropogenic influenced suboptimal/marginal habitat along the Morava River basin by European beaver

We suspect that the population in the study area is already close to its carrying capacity. At this stage any new settlement will generally be in more heavily anthropogenic influenced suboptimal/marginal habitat, where other habitat variables, other than willow, have increasing explanatory power. Beavers are very plastic animals that can survive and reproduce in different landscapes, including cultivated landscapes (Nolet and Rosell 1998); however, favorable beaver lodge/den sites decrease as anthropogenic activities increase (Fustec et al. 2003). Although winter food availability (e.g., sufficient stands of willow) may well be an important requirement for establishment of source colonies facilitating reproduction success (Tyurnin 1984), dispersal routes may play just as an important role in successful population expansion and stabilization. Baker et al. (2006) have suggested that habitats heavily influenced by human activities, such as those that exist in Great Britain, may provide the "combination and quality of a range of factors needed to accommodate...dispersing beavers." The results of the study have shown that during the later phases of expansion, beavers are indeed colonizing just such suboptimal/marginal habitat, which is heavily influenced by anthropogenic activities; however, they do not show the dynamics of beaver activity within this type of habitat.

\section{Conclusions}

The study has highlighted potential key stages in habitat selection within optimal habitat of an expanding reintroduced beaver population: (1) during the initial phases of expansion, beavers often ignore close-by resource poor sites to establish settlements at willow-rich sites; (2) during later phases of expansion, these initial settled sites appear to take on more significance as potential source colony sites; and (3) as all optimal sites become occupied and defended, beavers appear to colonize potential sink sites in heavily anthropogenic influenced suboptimal/marginal habitat.
The study also highlighted that the significance of both vegetative and physical variables changes over time, suggesting that vegetative variables are more significant during the early phases of expansion when beavers need, first and foremost, to establish resource-rich settlements to enable survival and reproduction, physical variables becoming more significant during the later phases of expansion when beavers begin to disperse into suboptimal sites. As well as providing buffers to the beaver settlements occupied first, these suboptimal sites can act as staging posts for further beaver expansion through heavily anthropogenic influenced habitats to more optimal habitats beyond.

Although previous research has addressed the issue of beaver dispersal through habitats heavily influenced by anthropogenic activities, we suggest that further more focused research is needed in this area. In fragmented habitats particularly, this issue may have a crucial part to play in the success or failure of an expanding beaver population.

Acknowledgments This study was supported by the Universities Development Foundation (FRVS G4 53/2004).

\section{References}

Aleksiuk M (1968) Scent-mound communication, territoriality, and population regulation in beaver (Castor canadensis Kuhl). J Mammal 49:759-762

Baker S, Fraser D, Kostkan V (2006) A modified method for appraising the suitability of urban sites in Great Britain, for use by the Eurasian (European) beaver (Castor fiber). J Practical Ecol Conservat 5:22-37

Barnes DM, Mallik AU (1997) Habitat factors influencing beaver dam establishment in a northern Ontario watershed. J Wildl Manage 61:1371-1377

Beer JR (1955) Movements of tagged beaver. J Wildl Manage 19:492-493

Beier P, Barrett RH (1987) Beaver habitat use and impact in the Truckee Basin, California. J Wildl Manage 51:794-799

Broschart MR, Johnston CA, Naiman RJ (1989) Predicting beaver colony density in boreal landscapes. J Wildl Manage 53:929-934

Calenge C (2006) The package "adehabitat" for the R software: a tool for the analysis of space and habitat use by animals. Ecol Model 197:516-519

Calenge C, Dufour A, Maillard D (2005) K-select analysis: a new method to analyse habitat selection in radio-tracking studies. Ecol Model 186:143-153

Campbell RD, Rosell F, Nolet BA, Dijkstra VAA (2005) Territory and group sizes in Eurasian beavers (Castor fiber): echoes of settlement and reproduction? Behav Ecol Sociobiol 58:597-607

Cohen J (1960) A coefficient of agreement for nominal scales. Educ Psychol Meas 20:37-46

Dieter CD, McCabe TP (1989) Factors influencing beaver lodge-site selection on a Prairie River. Am Mid Nat 122:408-411

Fryxell JM (2001) Habitat suitability and source-sink dynamics of beavers. J Anim Ecol 70:310-316 
Fustec J, Lode T, Le Jacques D, Cormier JP (2001) Colonization, riparian habitat selection and home range size in a reintroduced population of European beavers in the Loire. Freshwat Biol 46:1361-1371

Fustec J, Cormier JP, Lodé T (2003) Beaver lodge location on the upstream Loire River. CR Biol 326:192-199

Harrell FE (2007) Design: design package. R package version 2.1-1. Available via http://www.R-project.org

Hartman G (1994) Long-term population development of a reintroduced beaver (Castor fiber) population in Sweden. Conserv Biol 8:713-717

Hartman G (1995) Patterns of spread of a reintroduced beaver Castor fiber population in Sweden. Wildl Biol 1:97-103

Hartman G (1996) Habitat selection by European beaver (Castor fiber) colonizing a boreal landscape. J Zool 240:317-325

Hartman G (1997) Notes on age and dispersal of beaver (Castor fiber) in an expanding population. Can J Zool 75:959-962

Hartman G, Tornlov S (2006) Influence of watercourse depth and width on dam-building behaviour by Eurasian beaver (Castor fiber). J Zool 268:127-131

Hošek E (1966) Bobři v povodí horního toku řeky Moravy a jejích prítoků. Severní Morava 13:65-68

Howard RJ, Larson JS (1985) A stream habitat classification system for beaver. J Wildl Manage 49:19-25

Hutchinson GE (1957) Concluding remarks. Cold Spring Harbour Symp Quant Biol 22:415-427

Ihaka R, Gentleman R (1996) R: a language for data analysis and graphics. J Comput Graph Stat 5:299-314

John F (2006) Kolonizace povodí Moravy nad Olomoucí bobrem evropským (Castor fiber L.). In: Měkotová J, Štěrba O (eds), River Landscape 4. Olomouc, pp 86-95

John F (2009) Habitat selection by beavers: methodological aspects and results for a reintroduced beaver (Castor fiber L.) population in the Morava River basin. Ph.D. thesis, Palacky University, Olomouc

John F, Kostkan V (2009) Compositional analysis and GPS/GIS for study of habitat selection by the European beaver, Castor fiber in the middle reaches of the Morava River. Folia Zool $58: 76-86$

Kindschy RR (1985) Response of willow to beaver use in southeastern Oregon. J Wildl Manage 49:26-28

Kostkan V (2000) Ekologická nika bobra evropského (Castor fiber L. 1758) v Chráněné krajinné oblasti Litovelské Pomoraví. Ph.D. thesis, Palacky University, Olomouc
Kostkan V, Lehký J (1997) The Litovelské Pomoraví floodplain forest as a habitat for the reintroduction of the European beaver (Castor fiber) into Czech Republic. Global Ecol Biogeogr 6:307-310

Kostkan V, John F, Vávrová P (2002) Kácení dřevin bobrem evropským (Castor fiber L.) na střední Moravě. Přírodovědné studie Muzea Prostějovska 5:87-97

Landis JR, Koch GC (1977) The measurements of observer agreement for categorical data. Biometrics 33:159-174

Leege TA (1968) Natural movements of beavers in southeastern Idaho. J Wildl Manage 32:973-976

McComb WC, Sedell JR, Buchholz TD (1990) Dam-site selection by beavers in an eastern Oregon basin. Great Basin Naturalist 50:273-281

McNew L, Woolf A (2005) Dispersal and survival of juvenile beavers (Castor canadensis) in southern Illinois. The Am Mid Nat 154:217-228

Müller-Schwarze D, Sun L (2003) The beaver: natural history of a wetlands engineer. Cornell University Press, Ithaca

Nolet BA, Rosell F (1994) Territoriality and time budgets in beavers during sequential settlement. Can J Zool 72:1227-1237

Nolet BA, Rosell F (1998) Comeback of the beaver Castor fiber: an overview of old and new conservation problems. Biol Conserv $83: 165-173$

R Development Core Team (2007) R: A language and environment for statistical computing. R Foundation for Statistical Computing, Vienna, Austria. http://www.R-project.org

Robel JR, Fox LB, Kemp KE (1993) Relationship between habitat suitability index values and ground counts of beaver colonies in Kansas. Wildl Soc Bul 21:415-421

Schooley RL (1994) Annual variation in habitat selection: patterns concealed by pooled data. J Wildl Manage 58:367-374

Slough BG, Sadleir RMFS (1977) A land capability classification system for beaver (Castor canadensis). Can J Zool 55:1324-1335

Sun L, Müller-Schwarze D, Schulte BA (2000) Dispersal pattern and effective population size of the beaver. Can J Zool 78:393-398

Suzuki N, McComb WC (1998) Habitat classification models for beaver (Castor canadensis) in the streams of the central Oregon coast range. Northwest Sci 72:102-110

Šafáŕ J (2002) Novodobé rozšíření bobra evropského (Castor fiber L., 1758) v České republice. Příroda 13:161-196

Tyurnin BN (1984) Factors determining the numbers of the river beaver Castor fiber in the European north. Soviet Journal of Ecology 14:337-344

Zurowski W, Kasperczyk B (1990) Results of beaver reintroduction in some Carpathian mountain streams. Ochr Przyr 47:201-213 